\title{
Cultural characteristics, morphology, and variation within Claviceps africana and C. sorghi from India
}

\author{
Venkateshwaran MUTHUSUBRAMANIAN ${ }^{a, 1}$, Ranajit BANDYOPADHYAY ${ }^{a, 2}$, \\ Daram RAJARAM REDDY ${ }^{b}$, Paul W. TOOLEY, ${ }^{c}$ * \\ anternational Crops Research Institute for the Semi-Arid Tropics, Patancheru 502 324, Andhra Pradesh, India \\ ${ }^{b}$ Professor, Department of Plant Pathology, Acharya N. G. Ranga Agricultural University, Hyderabad-500 030, Andhra Pradesh, India \\ ${ }^{\mathrm{C}}$ USDA-ARS, Foreign Disease-Weed Science Research Unit, 1301 Ditto Ave., Ft. Detrick, MD 21702-5023, USA
}

\section{A R T I C L E I N F O}

\section{Article history:}

Received 18 January 2005

Received in revised form

14 November 2005

Accepted 16 December 2005

Published online 23 March 2006

Corresponding Editor: Jeffrey K. Stone

Keywords:

Clavicipitaceae

Ergot

Population biology

Sorghum

\begin{abstract}
A B S T R A C T
Sorghum ergot in India is caused by Claviceps africana and C. sorghi. The distributions of these two species in India is not known. Eighty-nine sorghum ergot isolates were cultured from young sphacelia obtained from male sterile sorghum plants artificially inoculated using inoculum collected in the field. Based on cultural characteristics, the isolates were separated into two groups which differed distinctly in the morphology of their sphacelia, conidia, and sclerotia. Marked differences also were observed in rates of secondary conidial production and disease spread between the groups. In combination with molecular evidence, our results confirm that the isolates placed in Group I represent C. africana and Group II isolates represent C. sorghi. C. africana was found to be widely distributed in all sorghum growing areas of India. The species first described as occuring in India, C. sorghi, appears to be restricted to a few locations in the states of Maharashtra, Andhra Pradesh, and Karnataka.
\end{abstract}

Published by Elsevier Ltd on behalf of The British Mycological Society.

\section{Introduction}

Ergot or sugary disease of sorghum (Sorghum bicolor) caused by Sphacelia sorghi is a serious threat to the production of $F_{1}$ hybrid seeds, particularly if nicking is poor or seed set is delayed in male sterile lines. The disease, initially restricted to Asia and Africa, attained global significance in the late 1990s after causing epidemics in the Americas and Australia (Bandyopadhyay et al. 1998; Pažoutová et al. 2000). Three different Claviceps species are known to cause sorghum ergot in different parts of the world viz., C. sorghi reported from India (Kulkarni et al. 1976), C. africana initially reported from Zimbabwe (Frederickson et al. 1991), and C. sorghicola reported from Japan (Tsukiboshi et al. 1999). In India, sorghum ergot has been reported since the early 1920s, in Maharashtra (Ajrekar 1926), Karnataka (Kulkarni 1942), Tamilnadu (Nath \& Padwick 1941; Thomas et al. 1945; Ramakrishnan 1947), Andhra Pradesh (Ramakrishnan 1948; Sundaram 1969; Patil et al. 1968), and Delhi and Haryana (AICSIP 1969-1970). Kulkarni et al. (1976) observed the teleomorph of Sphacelia sorghi and described it as C. sorghi. Ergot is endemic in the Indian states of Maharashtra (Vidarbha and Ahmednagar regions), Uttar Pradesh, Karnataka, Andhra Pradesh, and Tamilnadu (Bandyopadhyay et al. 2002).

Like all ergot species, sorghum ergot colonizes ovaries, inhibiting normal pollination, fertilization, and production of

\footnotetext{
${ }^{*}$ Corresponding author.

E-mail address: paul.tooley@ars.usda.gov

${ }^{1}$ Present address: Department of Plant Pathology, University of Wisconsin-Madison, 1630 Linden Drive, Madison, WI 53706, USA.

2 Present address: Plant Pathologist, International Institute of Tropical Agriculture, PMB 5320, Ibadan, Nigeria. 0953-7562/\$ - see front matter Published by Elsevier Ltd on behalf of The British Mycological Society. 
seed. Instead, the ovaries are colonized by fungal hyphae that develop into spore-bearing fungal masses (sphacelia), which later turn into hard sclerotia. An early report from India on cultural characters of the pathogen (Ajrekar 1926) describes the fungus as S. sorghi, which is the name applied to anamorph of both C. sorghi and C. africana. Colonies of S. sorghi on Kirchoff's medium are white with abundant aerial hyphae. Some Indian isolates cultured by Bogo and Mantle (1999) and putatively belonging to $C$. africana produced compact, white growth, which failed to produce spores on asparaginesucrose-salts agar medium. C. sorghicola is a third ergot-causing Claviceps species reported from Japan, which has white to cream-coloured, velvety colonies, and a hyphal growth rate of $1 \mathrm{~mm}^{-1 a y}{ }^{-1}$ at $25^{\circ} \mathrm{C}$ (Tsukiboshi et al. 1999).

The anamorph of $C$. africana and $C$. sorghi is recognized in planta by the presence of sphacelia, macroconidia, microconidia, and secondary conidia. The teleomorph phase of the pathogen begins with the production of sclerotia which upon germination give rise to ascomata, which bear ascospores. The three distinct Claviceps species differ in the morphology of their sphacelia, conidia, sclerotia, and ascomata (Bandyopadhyay et al. 1996; Frederickson et al. 1991; Tsukiboshi et al. 1999). The occurrence of C. africana in India, in addition to $C$. sorghi, which is apparently confined to the Indian sub continent (Frederickson et al. 1991), was confirmed by Bogo and Mantle (1999) on the basis of alkaloid analyses of sclerotia of Indian isolates via gas chromatography and mass spectrometry.

Tooley et al. $(2000,2002)$ reconfirmed the presence of C. africana in India, by means of random amplified microsatellite (RAM) and AFLP analyses, using sorghum ergot isolates collected from several locations in India. Pažoutová et al. (2000) confirmed the occurrence of C. africana in Dharwad (Karnataka), Patancheru (Andhra Pradesh) and Akola (Maharashtra), India through RAPD analysis and Pažoutová and Bogo (2001) showed using RAPDs and rDNA (ITS) sequence analysis that certain Indian isolates collected in 2000 were $C$. sorghi. Though there are several reports of the occurrence of both $C$. africana and C. sorghi in India, very little knowledge exist of their distribution or cultural characteristics such as comparative morphology of sphacelia, conidia, and sclerotia. It has been theorized (Bandyopadhyay et al. 2002; Pažoutová et al. 2000) that $C$. africana replaced C. sorghi as the primary ergot pathogen in India due to its increased ability to form airborne secondary conidia on the surface of abundant honeydew containing primary conidia. This ability would serve as a selective advantage during ergot epidemics, which could gradually result in the predominance of $C$. africana. In addition, C. sorghicola, which was reported from Japan (Tsukiboshi et al. 1999), has never been reported from India. However, its presence in India would be expected given patterns of global movement of sorghum seed. Similarity among Indian, Australian and Japanese isolates of C. africana for AFLP and RAPD markers were theorized to exist in part because of such patterns of seed movement (Komolong et al. 2002; Pažoutová et al. 2000; Tooley et al. 2002). To complete this study we conducted an extensive survey of sorghum growing regions in India. Our goals were to identify the Claviceps species causing sorghum ergot in India, determine the distribution of the species, describe the range of cultural and morphological features possessed by each species, and compare production of secondary conidia and rates of disease spread. Many of the isolates described in this study have been further characterized using AFLPs and analysis of selected DNA sequences in a companion study (Tooley et al. 2006).

\section{Materials and methods}

\section{Collection of isolates}

Sorghum ergot surveys were conducted from October 1999 to February 2000 to determine the incidence and severity of the disease in major sorghum-growing Indian states (Navi et al. 2002a,b). This study is based on 89 ergot collections from 59 locations in seven sorghum-growing states of India (Fig 1, Table 1). Individual locations were represented by up to eight collections. Disease incidence and severity at the 59 locations ranged from trace levels to $100 \%$ (Navi et al. 2002b). Between five and 25 infected panicles with honeydew or sclerotia were collected randomly from fields during the surveys. Isolates $\mathrm{KA} 58 \mathrm{~b}$ and $\mathrm{KA} 58 \mathrm{~b}-1$ represent separate isolates from two different sphacelia in the same panicle collected from Jalasangi, while isolates $\mathrm{KA} 61 \mathrm{~b}, \mathrm{c}, \mathrm{d}$, and e represent isolates from different panicles collected in ARS-Bidar. Latitude and longitude of the locations were measured using a hand-held global positioning system instrument (Magellan System, San Dimas, CA). In addition, collaborating scientists from the National Research Center for Sorghum (Hyderabad) and several state agricultural universities collected infected panicles from their research stations and provided samples for this study. Information on approximate geographic coordinates of these stations was gathered from maps or directly from the collaborators.

\section{Inoculation, isolation, and morphological characterization}

Panicles were brought to the International Crops Research Institute for the Semi-Arid Tropics (ICRISAT, Patancheru, India) for analysis. Two to five subsamples, each containing up to five panicles, were established from the field-collected infected sorghum panicles at each location. One subsample was dried under shade and preserved as an herbarium specimen for future reference. The remaining subsamples were used to isolate the pathogen following rejuvenation on sorghum plants. A rachis with at least three to five infected spikelets, containing either fresh or dried honeydew exudation was excised from one infected panicle of each isolate and suspended in sterile water to release the conidia. Some specimens did not have easily identifiable honeydew. For these specimens, sphacelia or sclerotia were carefully removed from spikelets, macerated in sterile water with a mortar and suspended in water. The inoculum suspension was filtered through two layers of cheesecloth (changed after each specimen), and adjusted to $1 \times 10^{6}$ propagules $\mathrm{ml}^{-1}$ using a haemocytometer.

Plants of male sterile sorghum genotype 296A were maintained in pots outdoors until the flag leaf stage, and then moved to a glasshouse. As tips of panicles began to emerge from the boot leaves, they were covered with pollination 


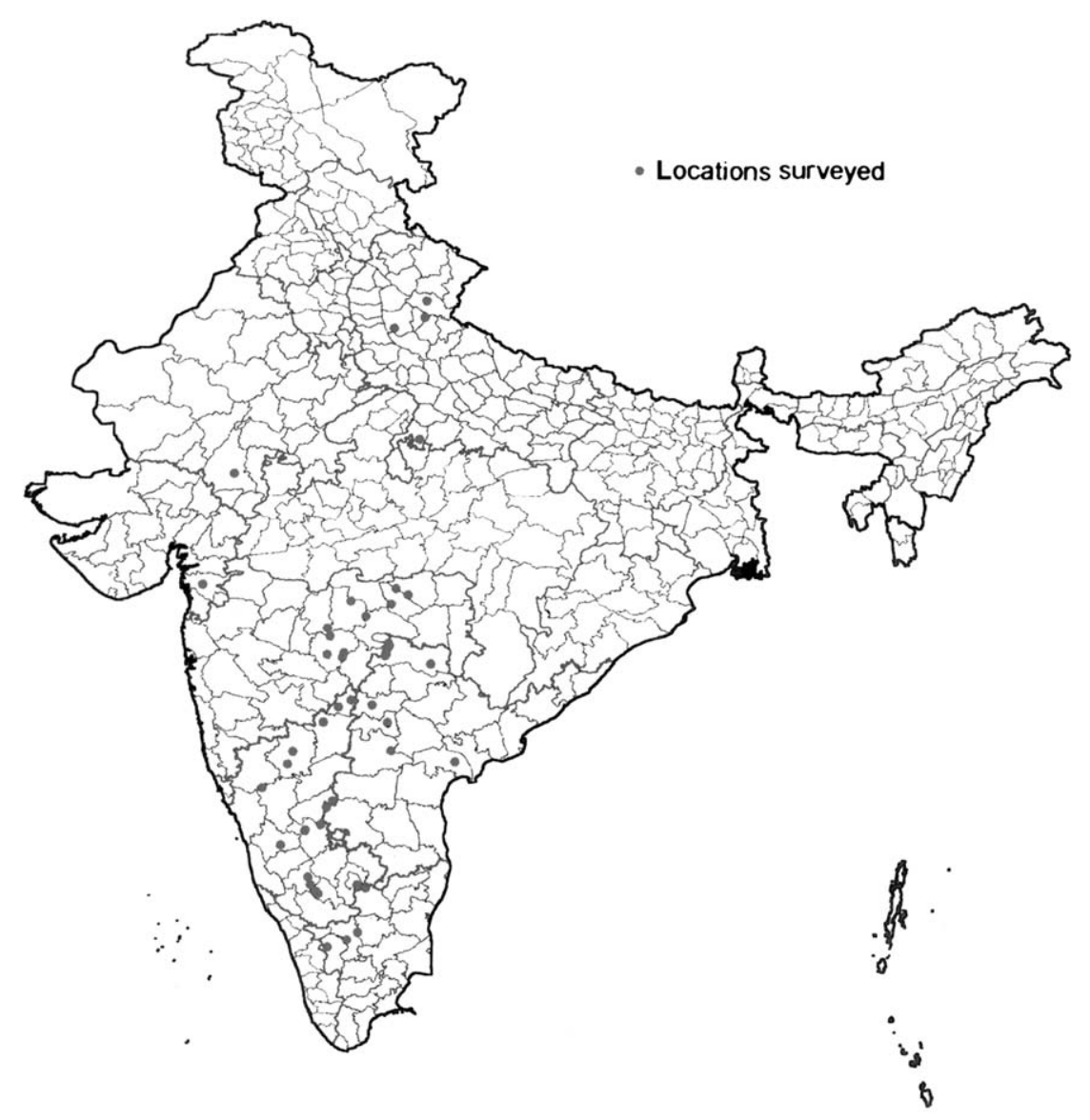

Fig 1 - Map of India, showing locations from which sorghum ergot was collected during the 1999-2000 season.

bags to avoid unintentional infection. At the $50 \%$ flowering stage, bags were briefly removed, panicles sprayed with inoculum suspension, and rebagged. At least three panicles were inoculated with each subsample. Inoculated plants were incubated for $24 \mathrm{~h}$ at $25{ }^{\circ} \mathrm{C}$ in a dew chamber to provide favourable conditions for infection after which plants were returned to the glasshouse for disease development.

Inoculated sorghum panicles were examined daily from $4 \mathrm{~d}$ postinoculation onward until the first appearance of white sphacelia between the glumes, which indicates successful infection (Bandyopadhyay et al. 1990). Spikelets with newlyformed ergot sphacelia were excised before they produced honeydew. The young sphacelia were teased out of glumes and surface-sterilized in $1 \%$ sodium hypochlorite for $3 \mathrm{~min}$ followed by five rinses in sterile distilled water. They were then transferred to $9 \mathrm{~cm}$ diam Petri plates containing T2 sucrose-asparagine-salts agar medium (Pažoutová et al. 2000) and incubated at $25^{\circ} \mathrm{C}$. At least ten sphacelia from each subsample were plated. Cultures of Claviceps africana and C. sorghi grew from the sphacelia on T2 agar, and subcultures of each isolate are deposited at the Indian Type Culture Collection [Department of Plant Pathology, Indian Agricultural Research Institute (IARI), New Delhi].

Growth and morphological characteristics of ten subcultured colonies from each isolate growing on T2 agar medium at $25{ }^{\circ} \mathrm{C}$ were recorded at $7 \mathrm{~d}$ intervals. The maximum colony diameter (following $30 \mathrm{~d}$ incubation at $25^{\circ} \mathrm{C}$ ), sporulation, colour, colony type, sulcate (puckering or folding of mycelial mass) nature, and pigmentation in the culture media were recorded for each isolate. The sulcate (puckering) nature of the colonies was recorded by using an arbitrary scale representing low, medium and high degree of puckering. Pigmentation was recorded using Munsell's colour chart (Munsell Products 1973). The growth rate of colonies $\left(\mathrm{mm} \mathrm{d}^{-1}\right)$ were calculated from colony diameter measured at weekly intervals.

The ergot collections were categorized on the basis of colony type and sporulation on T2 agar medium. After categorizing the collections, at least one isolate from each state where the group was present was randomly selected to represent each group.

\section{In vivo characterization of sphacelia, conidia and sclerotia}

Sorghum panicles of male sterile line 296A were inoculated with representative isolates as described above. Infected spikelets were sampled $7 \mathrm{~d}$ after inoculation and sphacelia were dissected out of the glumes without damaging the sphacelial tissues. The colour, shape, and size (length and breadth after cutting the sphacelia in half longitudinally) of 25 sphacelia of each isolate were recorded. Aqueous microscope slide mounts were made with $2 \mathrm{~d}$-old honeydew from infected panicles to observe shape, size, and constriction at the centre of 
Table 1 - Sources and cultural characteristics ${ }^{a}$ of 89 Indian Claviceps isolates collected between October 1999 and February 2000

\begin{tabular}{|c|c|c|c|c|c|c|c|}
\hline Isolate & State, district, locality (cultivar) & $\begin{array}{l}\text { Rate of } \\
\text { growth } \\
\left(\mathrm{mm} \mathrm{d}^{-1}\right)\end{array}$ & $\begin{array}{c}\text { Max. } \\
\text { radial } \\
\text { growth }^{\mathrm{b}}(\mathrm{cm})\end{array}$ & $\begin{array}{l}\text { Colony } \\
\text { type }\end{array}$ & $\begin{array}{c}\text { Puckering } \\
\text { nature }\end{array}$ & Pigmentation & Sporulation \\
\hline NAP1 & Andhra Pradesh, Ranga Reddy, Tammalonigudem (Local) & 0.04 & 1.3 & Compact & $\mathrm{L}$ & 2.5 YR $4 / 5$ & Absent \\
\hline NAP 2 & Andhra Pradesh, Nalagonda, Chakalisherupally (Yellow Jowar) & 0.04 & 1.21 & Compact & M & 2.5 YR 5/4 & Absent \\
\hline NAP3 & Andhra Pradesh, Nalgonda, Injamuru (Local) & 0.04 & 1.33 & Compact & $\mathrm{M} / \mathrm{H}$ & 2.5 YR $3 / 4$ & Absent \\
\hline NAP4 & Andhra Pradesh, Adilabad, Adigam (CSH9) & 0.11 & 3.27 & Cottony & Nil & 2.5 YR $6 / 6$ & Present \\
\hline NAP5 & Andhra Pradesh, Adilabad, Dongregaw (CSHO) & 0.11 & 3.25 & Cottony & Nil & 2.5 YR $6 / 6$ & Present \\
\hline NAP6 & Andhra Pradesh, Adilabad, Gudihatnur (CSH9) & 0.07 & 2.1 & Compact & $\mathrm{L}$ & 2.5 YR $5 / 6$ & Absent \\
\hline NAP7 & Andhra Pradesh, Adilabad, Sitagondi (CSH9) & 0.12 & 3.33 & Cottony & Nil & 2.5 YR $5 / 4$ & Present \\
\hline NAP8 & Andhra Pradesh, Medak, Chintakunta (CSH9) & 0.04 & 1.4 & Compact & $\mathrm{M}$ & 2.5 YR 5/6 & Absent \\
\hline NAP9 & Andhra Pradesh, Adilabad, Kamalapuram (CSH9) & 0.08 & 2.4 & Compact & $\mathrm{L}$ & 2.5 YR $5 / 5$ & Absent \\
\hline NAP10 & Andhra Pradesh, Adilabad, Mannur (CSH9) & 0.05 & 1.64 & Compact & $\mathrm{M}$ & 2.5 YR $4 / 6$ & Absent \\
\hline NAP11 & Andhra Pradesh, Adilabad, Naradegonda (CSH9) & 0.04 & 1.2 & Compact & $\mathrm{L}$ & 2.5 YR $4 / 5$ & Absent \\
\hline NAP12 & Andhra Pradesh, Adilabad, Kupti (CSH9) & 0.04 & 1.32 & Compact & $\mathrm{M}$ & 2.5 YR $5 / 6$ & Absent \\
\hline NAP13 & Andhra Pradesh, Adilabad, Burkapalle (JK 22) & 0.12 & 3.4 & Cottony & Nil & 2.5 YR 5.5/4 & Present \\
\hline APAU1 & Andhra Pradesh, Ranga Reddy, Rajendranagar (27B) & 0.05 & 1.52 & Compact & $\mathrm{L}$ & 2.5 YR 5/6 & Absent \\
\hline APAU2 & Andhra Pradesh, Ranga Reddy, Rajendranagar (296 B) & 0.04 & 1.22 & Compact & $\mathrm{L}$ & 2.5 YR $6 / 6$ & Absent \\
\hline APAU3 & Andhra Pradesh, Ranga Reddy, Rajendranagar (DSV 3) & 0.06 & 1.95 & Compact & $\mathrm{L}$ & 2.5 YR $6 / 6$ & Absent \\
\hline APAU4 & Andhra Pradesh, Ranga Reddy, Rajendranagar (CS 3541) & 0.04 & 1.24 & Compact & $\mathrm{L}$ & 2.5 YR $6 / 6$ & Absent \\
\hline APO & Andhra Pradesh, Medak, Patancheru (ICRISAT) (CSH9) & 0.05 & 1.6 & Compact & $\mathrm{M} / \mathrm{H}$ & 2.5 YR $6 / 6$ & Absent \\
\hline AP12 & $\begin{array}{l}\text { Andhra Pradesh, Mahabubnagar, Maachinenapally } \\
\text { (Yellow Jowar) }\end{array}$ & 0.05 & 1.56 & Compact & M & 2.5 YR $4 / 5$ & Absent \\
\hline AP13 & Andhra Pradesh, Mahabubnagar, Maachinenapally (SSG 878) & 0.06 & 1.9 & Compact & $\mathrm{L}$ & 2.5 YR $5 / 6$ & Absent \\
\hline AP14w & $\begin{array}{l}\text { Andhra Pradesh, Mahabubnagar, Maachinenapally } \\
\text { (White Jowar) }\end{array}$ & 0.06 & 1.73 & Compact & $\mathrm{L} / \mathrm{M}$ & 2.5 YR 5.5/6 & Absent \\
\hline AP14Y & $\begin{array}{l}\text { Andhra Pradesh, Mahabubnagar, Maachinenapally } \\
\text { (Yellow Jowar) }\end{array}$ & 0.05 & 1.5 & Compact & M & 2.5 YR $6 / 6$ & Absent \\
\hline AP15 & $\begin{array}{l}\text { Andhra Pradesh, Mahabubnagar, Maachinenapally } \\
\text { (Yellow Jowar) }\end{array}$ & 0.06 & 1.8 & Compact & $\mathrm{L}$ & 2.5 YR 5/6 & Absent \\
\hline AP16 & $\begin{array}{l}\text { Andhra Pradesh, Mahabubnagar, Maachinenapally } \\
\text { (Yellow Jowar) }\end{array}$ & 0.07 & 2.12 & Compact & $\mathrm{L}$ & 2.5 YR 5/6 & Absent \\
\hline AP16RB & Andhra Pradesh, Nalgonda, Chicholi (Yelllow Jowar) & 0.06 & 1.8 & Compact & $\mathrm{L}$ & 2.5 YR $5 / 6$ & Absent \\
\hline AP16VR & Andhra Pradesh, Guntur, Lam Farm (Local) & 0.04 & 1.25 & Compact & $\mathrm{L}$ & 2.5 YR 4/6 & Absent \\
\hline AP17 & Andhra Pradesh, Mahabubnagar, Maachinenapally (SSG 898) & 0.05 & 1.6 & Compact & $\mathrm{L}$ & 2.5 YR 5/6 & Absent \\
\hline KA41 & Karnataka, Bijapur, Muttagi (White Jowar) & 0.04 & 1.2 & Compact & $\mathrm{L}$ & 2.5 YR $6.5 / 6$ & Absent \\
\hline KA53a & Karnataka, Bijapur, Almel (Fodder sorghum) & 0.07 & 2.16 & Compact & $\mathrm{M}$ & 2.5 YR $3 / 5$ & Absent \\
\hline KA57b & Karnataka, Gulbarga, Rachnal (Hybrid sorghum) & 0.06 & 1.75 & Compact & $\mathrm{L}$ & 2.5 YR 5/6 & Absent \\
\hline KA58b & Karnataka, Bidar, Jalasangi (Yellow Jowar) & 0.05 & 1.5 & Compact & $\mathrm{M}$ & 2.5 YR $4 / 4$ & Absent \\
\hline KA58b-1 & Karnataka, Bidar, Jalasangi (Hybrid sorghum) & 0.06 & 1.75 & Compact & $\mathrm{M}$ & 2.5 YR $5 / 6$ & Absent \\
\hline KA61 & Karnataka, Bidar, ARS-Bidar (DKR 9501) & 0.06 & 1.77 & Compact & $\mathrm{M}$ & 2.5 YR $5 / 6$ & Absent \\
\hline KA61b & Karnataka, Bidar, ARS-Bidar (SVD 9601) & 0.08 & 2.37 & Compact & $\mathrm{M}$ & 2.5 YR 5/6 & Absent \\
\hline KA61c & Karnataka, Bidar, ARS-Bidar (DSV 2) & 0.04 & 1.35 & Compact & $\mathrm{L}$ & 2.5 YR $3 / 5$ & Absent \\
\hline KA61d & Karnataka, Bidar, ARS-Bidar (SHD 9704) & 0.06 & 1.75 & Compact & $\mathrm{M}$ & 2.5 YR $4 / 6$ & Absent \\
\hline KA61e & Karnataka, Bidar, ARS-Bidar (SPV 1333) & 0.08 & 2.53 & Compact & $\mathrm{L}$ & 2.5 YR 4/6 & $\begin{array}{c}\text { Absent } \\
\text { d on next page) }\end{array}$ \\
\hline
\end{tabular}




\begin{tabular}{|c|c|c|c|c|c|c|c|}
\hline Isolate & State, district, locality (cultivar) & $\begin{array}{l}\text { Rate of } \\
\text { growth } \\
\left(\mathrm{mm} \mathrm{d}^{-1}\right)\end{array}$ & $\begin{array}{c}\text { Max. } \\
\text { radial } \\
\text { growth }^{\mathrm{b}}(\mathrm{cm})\end{array}$ & $\begin{array}{l}\text { Colony } \\
\text { type }\end{array}$ & $\begin{array}{l}\text { Puckering } \\
\text { nature }\end{array}$ & Pigmentation & Sporulation \\
\hline SK1 & Karnataka, Mandya, Kbettali (Popcorn) & 0.06 & 1.9 & Compact & $\mathrm{L}$ & 2.5 YR 5/6 & Absent \\
\hline SK2 & Karnataka, Mandya, Chinakurali (Yellow Jowar) & 0.05 & 1.52 & Compact & $\mathrm{M} / \mathrm{H}$ & 2.5 YR $3 / 2$ & Absent \\
\hline SK3 & Karnataka, Mandya, Thendekere (Local) & 0.04 & 1.25 & Compact & $\mathrm{L}$ & 2.5 YR $5 / 6$ & Absent \\
\hline SK5 & Karnataka, Mandya, Laxmipura (Ogarujola) & 0.05 & 1.4 & Compact & $\mathrm{L} / \mathrm{H}$ & 2.5 YR $4 / 4$ & Absent \\
\hline SK7 & Karnataka, Hassan, Darsigatta (Ogarujola) & 0.08 & 2.43 & Compact & $\mathrm{L} / \mathrm{M}$ & 2.5 YR $4 / 6$ & Absent \\
\hline SK12 & Karnataka, Chitradurga, Hirebennur (CSH 5) & 0.05 & 1.52 & Compact & $\mathrm{M}$ & 2.5 YR $3 / 4$ & Absent \\
\hline SK13 & Karnataka, Chitradurga, Obavvanagathi halli (Local) & 0.05 & 1.6 & Compact & $\mathrm{M} / \mathrm{H}$ & 2.5 YR $3 / 3$ & Absent \\
\hline SK16 & Karnataka, Chitradurga, Talaku (MSH 51) & 0.06 & 1.9 & Compact & M & $2.5 \mathrm{YR} 4 / 5$ & Absent \\
\hline SK17 & Karnataka, Chitradurga, Bommadevanahalli (MSH 51) & 0.05 & 1.16 & Compact & $\mathrm{L}$ & 2.5 YR $6 / 6$ & Absent \\
\hline SK-5-21 & Karnataka, Bangalore, Neralur (Fodder sorghum) & 0.05 & 1.43 & Compact & $\mathrm{L}$ & 2.5 YR $4 / 6$ & Absent \\
\hline SK-14-23 & Karnataka, Shimoga, Hasalli (Ogarujola) & 0.05 & 1.65 & Compact & $\mathrm{L}$ & 2.5 YR 5/6 & Absent \\
\hline SK-20-24 & Karnataka, Chitradurga, Talaku (MSH 51) & 0.03 & 1.12 & Compact & $\mathrm{L}$ & 2.5 YR 4/6 & Absent \\
\hline SK-22-24 & Karnataka, Bellary, Amarapura (GK 52) & 0.04 & 1.42 & Compact & M & $2.5 \mathrm{YR} 4 / 6$ & Absent \\
\hline UASD1 & Karnataka, Dharwad, Agricultural College (CSH 13) & 0.09 & 2.93 & Compact & $\mathrm{L}$ & 2.5 YR 5/6 & Absent \\
\hline AK1 & Maharashtra, Akola, Akola (unknown cultivar) & 0.04 & 1.4 & Compact & $\mathrm{L}$ & 2.5 YR 5/6 & Absent \\
\hline MH67 & Maharashtra, Akola, Risode (CSH 9) & 0.05 & 1.4 & Compact & $\mathrm{M}$ & 2.5 YR $4 / 6$ & Absent \\
\hline MH70 & Maharashtra, Akola, Mana (Nilva local) & 0.07 & 2.18 & Compact & $\mathrm{M}$ & 2.5 YR $6 / 6$ & Absent \\
\hline MH71 & Maharashtra, Nagpur, Chembeli (Mottura) & 0.06 & 1.73 & Compact & $\mathrm{L}$ & 2.5 YR $5 / 4$ & Absent \\
\hline MH72 & Maharashtra, Nagpur, Mahagaon (Kaderu local) & 0.05 & 1.61 & Compact & $\mathrm{L}$ & 2.5 YR $5 / 4$ & Absent \\
\hline MH73 & Maharashtra, Wardha, Salod (Pandharpuri) & 0.05 & 1.43 & Compact & $\mathrm{L}$ & 2.5 YR 5/6 & Absent \\
\hline MH74 & Maharashtra, Yavatmal, Bori (CSH 14) & 0.12 & 3.52 & Cottony & Nil & 2.5 YR $4 / 4$ & Present \\
\hline MH75 & Maharashtra, Nanded, Malegaon (Gulbhendi red) & 0.04 & 1.2 & Compact & $\mathrm{L}$ & 2.5 YR 5/6 & Absent \\
\hline MH76 & Maharashtra, Nanded, Limbgaon (Pandrapiwala) & 0.05 & 1.42 & Compact & $\mathrm{L}$ & 2.5 YR $4 / 4$ & Absent \\
\hline MH78 & Maharashtra, Parbhani, SRS-Parbhani (CSH 9) & 0.05 & 1.63 & Compact & $\mathrm{L}$ & 2.5 YR 5/6 & Absent \\
\hline MH79 & Maharashtra, Parbhani, SRS-Parbhani (SPV 1333) & 0.04 & 1.27 & Compact & $\mathrm{L}$ & 2.5 YR $3 / 4$ & Absent \\
\hline MH80 & Maharashtra, Parbhami, SRS-Parbhani (Nilwa local) & 0.07 & 2.2 & Compact & $\mathrm{L}$ & 2.5 YR $4 / 6$ & Absent \\
\hline NI1 & Uttar Pradesh, Rampur, Rampur (Local) & 0.07 & 2.24 & Compact & $\mathrm{M}$ & 2.5 YR $5 / 6$ & Absent \\
\hline NI2 & Uttar Pradesh, Jhansi, Mouranipur (SBPR 94004) & 0.05 & 1.63 & Compact & $\mathrm{M} / \mathrm{H}$ & 2.5 YR $5 / 6$ & Absent \\
\hline NI3 & Uttar Pradesh, Jhansi, Mouranipur (ICSA 696) & 0.05 & 1.52 & Compact & $\mathrm{H}$ & 2.5 YR $4 / 4$ & Absent \\
\hline NI4 & Uttar Pradesh, Nainital, Pantnagar (ICSB 91002) & 0.05 & 1.45 & Compact & M & 2.5 YR 5/4 & Absent \\
\hline NI5 & Uttar Pradesh, Nainital, Pantnagar (2219 A) & 0.05 & 1.4 & Compact & $\mathrm{M}$ & 2.5 YR $4 / 4$ & Absent \\
\hline NI6 & Uttar Pradesh, Nainital, Pantnagar (2219 A) & 0.06 & 1.76 & Compact & $\mathrm{M}$ & 2.5 YR $4 / 4$ & Absent \\
\hline NI7 & Uttar Pradesh, Moradabad, Droli (Local) & 0.06 & 1.86 & Compact & $\mathrm{H}$ & 2.5 YR $4.5 / 4$ & Absent \\
\hline NI8 & Uttar Pradesh, Moradabad, Didoli/Deroli (Local) & 0.06 & 1.9 & Compact & M & 2.5 YR $3 / 4$ & Absent \\
\hline NI9 & Uttar Pradesh, Rampur, Kunapur (Local) & 0.05 & 1.55 & Compact & $\mathrm{H}$ & 2.5 YR $5 / 4$ & Absent \\
\hline NI10 & Uttar Pradesh, Moradabad, Sonali (Local) & 0.07 & 1.97 & Compact & $\mathrm{M}$ & 2.5 YR $5 / 6$ & Absent \\
\hline NI11 & Rajasthan, Udaipur, RCA1 (SU 1A) & 0.05 & 1.42 & Compact & $\mathrm{H}$ & 2.5 YR $4.5 / 4$ & Absent \\
\hline NI12 & Rajasthan, Udaipur, RCA2 (SU 14A) & 0.04 & 1.28 & Compact & $\mathrm{M} / \mathrm{H}$ & 2.5 YR $5 / 4$ & Absent \\
\hline NI13 & Rajasthan, Udaipur, RCA3 (SU 27A) & 0.03 & 1.05 & Compact & $\mathrm{M}$ & 2.5 YR $5 / 4$ & Absent \\
\hline TN6 & Tamilnadu, Dharmapuri, Nallgankothapalli (Yellow Jowar) & 0.06 & 1.8 & Compact & $\mathrm{M}$ & 2.5 YR $4 / 4$ & Absent \\
\hline TN10 & Tamilnadu, Namakkal, Muniyappan Kovil (Solan local) & 0.05 & 1.4 & Compact & $\mathrm{L}$ & 2.5 YR 5/4 & Absent \\
\hline TN11 & Tamilnadu, Erode, Totivalayam (Manjal jolam local) & 0.05 & 1.6 & Compact & $\mathrm{L}$ & 2.5 YR $5 / 4$ & Absent \\
\hline TN12 & $\begin{array}{l}\text { Tamilnadu, Coimbatore, TNAU, Millets scheme } \\
\text { (Doddamanga jola local) }\end{array}$ & 0.04 & 1.33 & Compact & $\mathrm{L}$ & 2.5 YR $5 / 4$ & Absent \\
\hline
\end{tabular}




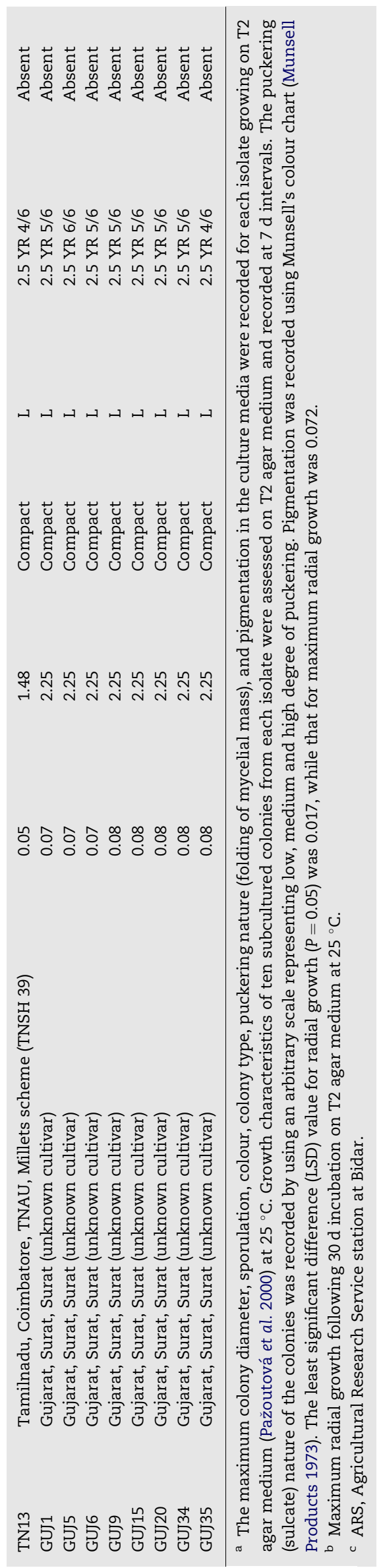

macroconidia. Since large numbers of microconidia are found in honeydew obtained after several days of exudation (Bandyopadhyay et al. 1990), size and shape of microconidia were recorded in aqueous mounts made from $30 \mathrm{~d}$-old honeydew that were almost dry or thick in consistency. Fifty macroconidia and microconidia were measured for each isolate.

Sclerotium collected during the survey of sorghum-growing areas were used to assess sclerotia morphology as panicles inoculated in the greenhouse did not produce sclerotia even after incubating infected plants in hot and dry conditions as specified by Bandyopadhyay et al. (1990). Only those collections that contained sclerotia could be used in this study. Observations were made using sclerotia with a sphacelial cap at their tip and also after carefully removing the sphacelial cap. Sphacelial caps were removed by immersing the sclerotia in warm water and using forceps to remove the sphacelial tissues from their tips without damaging the sclerotial tissues (Frederickson et al. 1999). Size (length and breadth), shape, and colour of 25 sclerotia per collection were recorded.

\section{Production of secondary conidia}

The same ten isolates used for in vivo characterization of sphacelia were used to study variation in secondary conidia production at different temperatures and relative humidity (RH) levels. Panicles of sorghum line 296A were inoculated as described above. The day before the expected appearance of honeydew (5 d after inoculation), plants were transferred to a growth chamber maintained at $25{ }^{\circ} \mathrm{C}$ with $\mathrm{RH}<70 \%$ to allow formation of honeydew but suppress secondary conidia production. From these panicles, rachis containing at least six spikelets with 2 d-old honeydew were carefully excised without allowing the honeydew to drop. The basal end of the excised rachis was inserted into a $100 \mathrm{ml}$ conical flask or $20 \mathrm{ml}$ vial containing $2 \%$ sucrose solution covered with Parafilm to support the spikelets. For each isolate, two rachis branches were inserted in each conical flask or vial for temperature or RH studies, respectively.

To study the effect of temperature on secondary conidia production, spikelets containing honeydew were incubated in the dark for $18 \mathrm{~h}$ at $10,15,20,25,30$ and $35{ }^{\circ} \mathrm{C}$ in dew chambers at $100 \% \mathrm{RH}$. The effect of $\mathrm{RH}$ on secondary conidia production was determined in specially built single plant chambers which offer precise control of RH (Butler et al. 1995). The chambers were made of glass jars and moist air was continuously blown in. Depending on the $\mathrm{RH}$ requirement, a micrologger (model CR21X; Campbell Scientific, Norah Logan, UT) measured RH in each chamber every $10 \mathrm{~s}$ and adjusted it to the desired level by pumping dry air into the chamber (Butler et al. 1995). Vials containing spikelets with honeydew were incubated in these chambers in the dark for $18 \mathrm{~h}$ at $80,85,90,95$, and $100 \% \mathrm{RH}$. The single plant chambers were placed in a growth chamber maintained at $25^{\circ} \mathrm{C}$.

After incubation at different temperature and $\mathrm{RH}$ regimes, four infected spikelets with honeydew from each replication were carefully excised from the rachis and collected in $25 \mathrm{ml}$ beakers containing $10 \mathrm{ml}$ sterile water. Spikelets were agitated in water with the aid of a magnetic stirrer to dissolve the honeydew. Macroconidia (1000 per treatment) were observed 
under a microscope to determine the proportion of macroconidia that produced secondary conidia. Macroconidia that produced germ tubes with a pointed distal end and were devoid of cytoplasm were considered to have germinated to produce secondary conidia (Bandyopadhyay et al. 1990). Experiments were conducted in a randomized block design with three replications, and repeated three times for a total of nine observations per isolate at each temperature and $\mathrm{RH}$ level.

\section{Assessment of ergot disease spread in the growth chamber}

The relative efficiency of aerial spread of sorghum ergot was compared under controlled conditions in growth chambers using two isolates (NI2 and NAP7) belonging to separate groups. Plants of male sterile sorghum line 296A were grown in $25 \mathrm{~cm}$-diameter plastic pots (two plants per pot) in the greenhouse. Panicles were covered with pollination bags immediately after emergence through boot leaves to avoid contamination from external inoculum. One week before the start of the experiment, six plants (sown 7-10 d earlier than others) were inoculated with either NI2 or NAP7 using the methods described above. Two days after the appearance of honeydew, one pot with each isolate was incubated overnight in separate dew chambers to allow the production of secondary conidia. These infected plants acted as a source of inoculum and were separately placed at the centre of two growth chambers. Twenty-two test plants (the number that could be accommodated in a single growth chamber) at the $50 \%$ flowering stage were placed around each pot containing the inoculum source, and the pollination bags covering the panicles were removed. The growth chambers were maintained at $25 \pm 1{ }^{\circ} \mathrm{C}$ and $97-100 \% \mathrm{RH}$ with a $12 \mathrm{~h}$ photoperiod to encourage secondary conidia production on the inoculum source plants and to allow infection on the test plants. The proportion of infected plants (disease incidence), number of infected spikelets, and total number of spikelets on each plant were recorded $5 \mathrm{~d}$ after symptoms appeared. The percent of spikelets infected on each plant was averaged to determine disease severity. The experiment was repeated three times.

\section{Statistical analysis}

Data were analysed by analysis of variance (ANOVA) using the GENSTAT statistical package (Lane \& Payne 1999) and the SAS statistical package (SAS Institute 1999). Analysis of covariance was used in SAS PROC GLM to assess the linear and quadratic effects of temperature and $\mathrm{RH}$ on production of secondary conidia. Estimates of linear combinations of parameters ('estimate' statements) were made using PROC GLM to compare Group I and II means and slopes.

\section{Results}

\section{Colony characteristics}

Isolates differed in the rate of colony growth, maximum radial growth, colony type, puckering nature (number of sulci) and sporulation on T2 agar medium (Table 1). Growth was cottony, velvety and submerged with diffused margins in five isolates (NAP4, NAP5, NAP7, NAP13, and MH74; Fig 2A). The remaining isolates had compact, fleshy and raised colonies with distinct margins (Fig 2B). Cultures of all isolates were white. The isolates differed with respect to the sulcate (puckering) nature of the colonies. Of the 89 isolates studied, five isolates (NAP4, NAP5, NAP7, NAP13, and MH74) showed no puckering whereas 47 isolates showed a low degree of puckering, 27 isolates showed a medium degree of puckering, and ten isolates showed a high degree of puckering (Table 1).

Different sorghum ergot isolates produced pigmentation on T2 agar medium ranging from dusky red to light red with a hue and value/chroma reading of 2.5 YR $3 / 3$ to 2.5 YR $6 / 6$
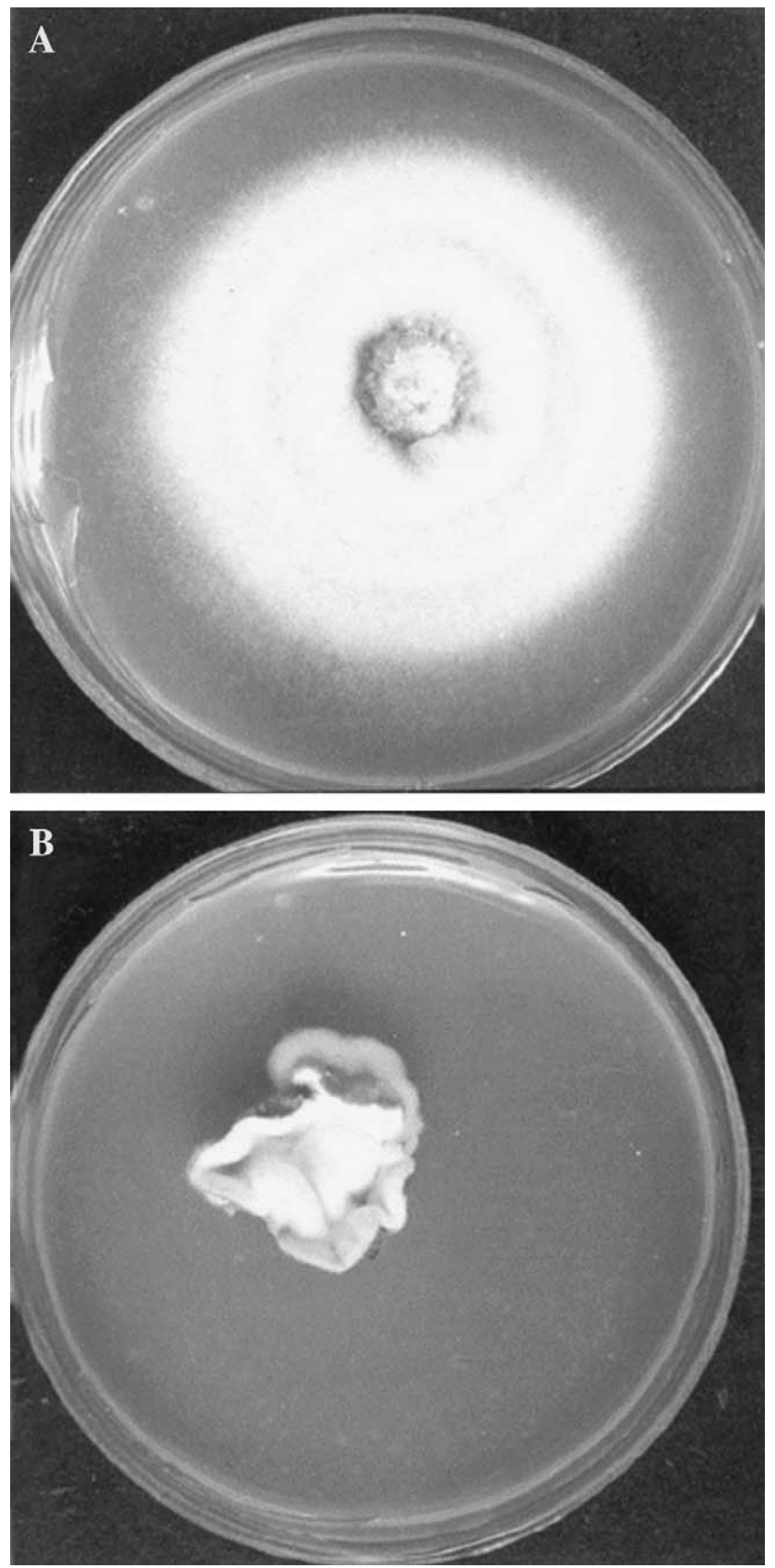

Fig 2 - Pure cultures of isolate NAP7 (Group II) on T2 agar medium (A); and isolate NI2 (Group I) on T2 agar medium (B). 
in Munsell's colour chart (Table 1). Sporulation was observed in cultures of only five isolates (NAP4, NAP5, NAP7, NAP13, and MH74) after 20-25 d of incubation on T2 medium whereas none of the other isolates sporulated on the medium even after $30 \mathrm{~d}$ at $25^{\circ} \mathrm{C}$ (Table 1). Sporulation was observed at the centre of the colony as minute droplets of honeydew secretions containing both macroconidia and microconidia which were infective on sorghum male sterile line 296A. The secretions were pale brown in colour and were thick in consistency. The maximum radial growth (colony diameter) of colonies of the various isolates ranged from $1.12-3.52 \mathrm{~cm}$ (Table 1).

\section{Grouping of isolates}

Isolates were grouped on the basis of growth rate, colony type and sporulation on T2 agar medium. Two distinct groups were observed: Group I consisted of 84 isolates having a slower growth rate $\left(0.03-0.09 \mathrm{~mm} \mathrm{~d}^{-1}\right)$, compact and raised colonies, and Group II contained five isolates (NAP4, NAP5, NAP7, NAP13, and MH74) having a comparatively higher growth rate (0.11-0.12 $\left.\mathrm{mm} \mathrm{d}^{-1}\right)$, cottony or velvety, submerged colonies with diffused margins and sporulation on T2 agar medium. Eight isolates belonging to Group I and representing geographic diversity within India were selected for further studies: NI2, NI5, NI12, GUJ6, MH71, SK-20-24, AP17, and TN13 (Table 1). Similarly, two isolates (NAP7 and MH74) were chosen as representatives of Group II for comparative studies.

\section{Sphacelia, conidia and sclerotia}

The isolates belonging to Groups I and II varied with respect to morphology of sphacelia, conidia and sclerotia. The sphacelia of Group I isolates measured $2.92-3.60 \times 1.90-2.26 \mathrm{~mm}$ and were conical to spherical, whereas the sphacelia of Group II isolates measured $4.38-4.72 \times 2.94-3.06 \mathrm{~mm}$ and were oblong to cylindrical in shape (Table 2, Fig 3A). Group II sphacelia length and breadth measurements were significantly larger $(P<0.0001)$ than those of Group I isolates when compared using 'estimate' statements in Proc GLM in SAS. Both groups had white sphacelia (Table 2).

Macroconidia belonging to the two distinct groups of isolates varied in size and shape. The macroconidia of isolates belonging to Group I were oblong to ellipsoidal with mean length/breadth measurements of 12.9-15.4 × 7.5-8.3 $\mu \mathrm{m}$ (range 10.3-18.0 $\times 6.4-9.0 \mu \mathrm{m})$, whereas, the macroconidia of Group II isolates were narrower, cylindrical, and somewhat smaller with mean length/breadth of 13.1-13.4 ×5.9-6.3 $\mu \mathrm{m}$ (range 9.0-18.0 $\mu \mathrm{m} \times 5.1-7.7 \mu \mathrm{m}$ (Table 3). Length and breadth of macroconidia of Group II isolates were significantly smaller $(P<0.0001)$ than those of Group I isolates when compared with 'estimate' statements in SAS.

Conidia of all isolates were hyaline and showed a slight constriction at the centre with two vacuoles, one at each end. Even though some variation was observed among Group I isolates in microconidia diameter (Table 3), Groups I and II did not differ significantly from one another $(\operatorname{Pr}>t=0.1739)$ when group means were compared using 'estimate' statements in SAS. This observation supports the hypothesis that the size and shape of microconida remains highly consistent throughout the genus Claviceps (Pažoutová et al. 2004).
Table 2 - Morphological characteristics of sphacelia of representative sorghum ergot isolates from Groups I and II

\begin{tabular}{|c|c|c|c|c|}
\hline Isolate & $\begin{array}{l}\text { Length }{ }^{a, b} \\
(\mathrm{~mm})\end{array}$ & $\begin{array}{l}\text { Breadth }^{\mathrm{a}, \mathrm{b}} \\
(\mathrm{mm})\end{array}$ & Shape & Colour \\
\hline \multicolumn{5}{|l|}{ Group I } \\
\hline NI2 & $2.92 \mathrm{~g}$ & $1.96 \mathrm{e}$ & $\begin{array}{l}\text { Elliptical to } \\
\text { conical }\end{array}$ & White \\
\hline NI5 & $3.02 \mathrm{fg}$ & $1.94 \mathrm{e}$ & Elliptical & White \\
\hline NI12 & $3.14 \mathrm{ef}$ & $2.00 \mathrm{de}$ & Elliptical & White \\
\hline GUJ6 & $3.38 \mathrm{~d}$ & $2.26 \mathrm{c}$ & $\begin{array}{l}\text { Spherical to } \\
\text { elliptical }\end{array}$ & White \\
\hline MH71 & $3.24 \mathrm{de}$ & $1.94 \mathrm{e}$ & Conical & White \\
\hline SK-20-24 & $3.60 c$ & $2.08 d$ & $\begin{array}{l}\text { Elliptical to } \\
\text { spherical }\end{array}$ & White \\
\hline AP17 & 3.16 ef & $1.90 \mathrm{e}$ & Elliptical & White \\
\hline TN13 & 3.16 ef & $1.92 \mathrm{e}$ & Elliptical & White \\
\hline \multicolumn{5}{|l|}{ Group II } \\
\hline NAP7 & $4.72 \mathrm{a}$ & $3.06 \mathrm{a}$ & $\begin{array}{l}\text { Oblong to } \\
\text { elliptical }\end{array}$ & White \\
\hline MH74 & $4.38 \mathrm{~b}$ & $2.94 \mathrm{~b}$ & $\begin{array}{l}\text { Oblong to } \\
\text { elliptical }\end{array}$ & White \\
\hline $\begin{array}{l}\text { Least significant } \\
\text { difference value } \\
(P=0.05)\end{array}$ & 0.17 & 0.12 & & \\
\hline \multicolumn{5}{|c|}{$\begin{array}{l}\text { Overall means of Groups I and II for length and breadth varied sig- } \\
\text { nificantly from one another, } P<0.0001 \text {. } \\
\text { a Mean of } 25 \text { sphacelia. } \\
\text { b Means within a column followed by a common letter(s) are not } \\
\text { significantly different at the } 5 \% \text { level. }\end{array}$} \\
\hline
\end{tabular}

None of the isolates produced sclerotia in at $35{ }^{\circ} \mathrm{C}$ and $40 \%$ $\mathrm{RH}$ in the controlled environment. Sclerotia collected in the field showed variation in size and shape, although Group I isolates always were observed to have smaller sclerotia compared with Group II isolates (Fig 3B). Sclerotia of Group I isolates with sphacelial cap were conical to spherical with mean length/ breadth dimensions of 4.10-4.42 × 1.40-1.82 mm. Sclerotia of Group II isolates with sphacelial cap were cylindrical to conical, with mean length/breadth dimensions of 8.16$9.60 \times 1.82-2.04 \mathrm{~mm}$. Length and breadth of sclerotia with sphacelial cap of Group II isolates were significantly greater $(P<0.0001)$ than those of Group I isolates when compared using 'estimate' statements in SAS. Some variation in sclerotial morphological was observed within Groups (Table 4).

Significant differences $(P=0.05)$ were also observed among isolates in the size of sclerotia minus the sphacelial cap. Sclerotia of Group I isolates were $2.20-2.30 \times 1.20-1.30 \mathrm{~mm}$ and conical to spherical, whereas those of Group II were 3.70$3.90 \times 2.00-2.30 \mathrm{~mm}$, oblong to cylindrical (Table 4). The colour of the sclerotia of Group II isolates minus the sphacelial cap was reddish brown with a hue and value/chroma reading of 5YR 5/4 in Munsell's colour chart. Group I sclerotia were reddish brown with a hue and value/chroma of 5YR 4/4, which is darker compared with Group II.

\section{Production of secondary conidia}

The effects of a range of temperatures $\left(10-35^{\circ} \mathrm{C}\right)$ and relative humidity $(\mathrm{RH})$ levels $(80-100 \%)$ on secondary conidia 

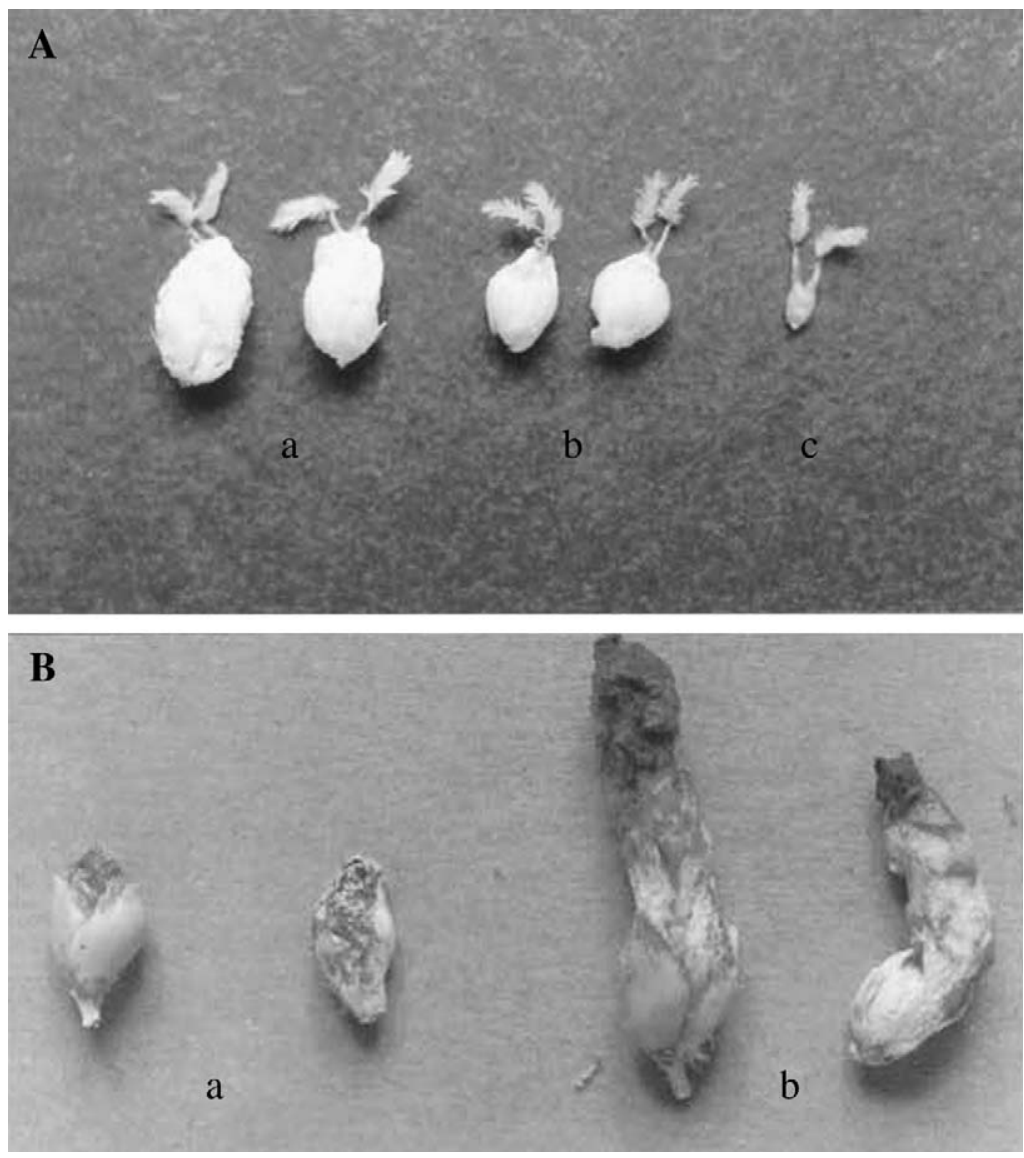

Fig 3 - Mature sphacelia (A) of two distinct groups: a, isolate NAP7 (Group II); b, isolate NI2 (Group I); c, uninfected ovary. Sclerotia (B) with sphacelial cap: a, isolate SK-20-24 (Group I); b, isolate NAP7 (Group II).

production was assessed by counting the number of germinated macroconidia (Fig 4). Over a wide range of temperatures and RH, Group II isolates produced significantly fewer secondary conidia compared with Group I isolates (Fig 4). The optimum temperature for secondary conidia production was $25^{\circ} \mathrm{C}$ for all isolates. Isolate NI2 (Group 1) was the most prolific secondary conidia producer (a mean of 128.8 secondary conidia were produced out of 1000 macroconidia observed at the optimum temperature of $25^{\circ} \mathrm{C}$ ) and NAP7 (Group II) the least prolific (a mean of 4.4 secondary conidia were produced at $\left.25^{\circ} \mathrm{C}\right)$.

Secondary conidia production varied significantly at different temperatures and among pathogen isolates (Fig 4A). At $20{ }^{\circ} \mathrm{C}$, secondary conidia production by all isolates followed the same trend observed at $25^{\circ} \mathrm{C}$. At $15^{\circ} \mathrm{C}$, secondary conidia production was reduced for almost all isolates except AP17, which produced its maximum number of secondary conidia (mean $=27.56)$ at this temperature. Few secondary conidia were produced at the lowest $\left(10^{\circ} \mathrm{C}\right)$ and highest temperatures $\left(35^{\circ} \mathrm{C}\right)$ examined. Isolates varied significantly in their linear and quadratic slope estimates (Table 5), indicating that the intensity of the response to temperature varied among isolates. Most of the variation was observed within Group I isolates as such low overall macroconidia germination was observed for Group II isolates. Using 'estimate' statements in SAS, significant differences $(P<0.0001)$ were observed between Groups 1 and II in overall means, and in linear and quadratic slopes.

Secondary conidia production also varied with $\mathrm{RH}$ levels (Fig 4B). As for temperature, all isolates belonging to Group I produced more secondary conidia than Group II (11) isolates. Isolate NI2 (Group I) produced the maximum number of secondary conidia (111.3 at $25^{\circ} \mathrm{C}$ and $100 \% \mathrm{RH}$ ), followed by NI12, while the isolates belonging to Group II produced low numbers of secondary conidia even at the most favourable conditions ( $25{ }^{\circ} \mathrm{C}$ and $100 \% \mathrm{RH}$ ). Maximum secondary conidia production was observed at high $\mathrm{RH}$ in all the isolates tested. With a decrease in $\mathrm{RH}$, secondary conidia production showed a decreasing trend with the lowest amount observed at $80 \%$ $\mathrm{RH}$. The rate of increase in secondary conidia production was comparatively low between 80 and $95 \%$ RH and high between 95 and $100 \%$ RH. Isolates varied significantly in their linear and quadratic slope estimates (Table 5). As for temperature, 'estimate' statements were used in SAS to compare overall means and linear and quadratic slopes of Group I versus Group II isolates and the groups significantly differed $(P<0.0001)$ in each case. As observed for the temperature response, most of the observed variation was within the Group I isolates, as low overall macroconidia germination was observed for the Group II isolates. 
Table 3 - Morphological characteristics of macroconidia and microconidia of representative sorghum ergot isolates from Group I and Group II

\begin{tabular}{|c|c|c|c|c|c|c|c|}
\hline \multirow[t]{2}{*}{ Isolate } & \multicolumn{3}{|c|}{ Macroconidia $^{a, b}$} & \multicolumn{4}{|c|}{ Microconidia $^{a, b}$} \\
\hline & $\begin{array}{l}\text { Length } \\
(\mu \mathrm{m})\end{array}$ & $\begin{array}{l}\text { Breadth } \\
\quad(\mu \mathrm{m})\end{array}$ & Shape & Colour & $\begin{array}{l}\text { Diameter } \\
(\mu \mathrm{m})\end{array}$ & Shape & Colour \\
\hline \multicolumn{8}{|l|}{ Group I } \\
\hline NI2 & $15.1 \mathrm{a}$ & $7.9 \mathrm{bc}$ & Oblong to ellipsoidal & Hyaline & $2.8 \mathrm{a}$ & Spherical & Hyaline \\
\hline NI5 & $15.4 \mathrm{a}$ & $7.7 \mathrm{c}$ & Oblong to ellipsoidal & Hyaline & $2.7 \mathrm{bcd}$ & Spherical & Hyaline \\
\hline NI12 & $14.7 \mathrm{a}$ & $8.3 b$ & Oblong to ellipsoidal & Hyaline & $2.7 \mathrm{ab}$ & Spherical & Hyaline \\
\hline GUJ6 & $12.9 \mathrm{~b}$ & $7.7 \mathrm{c}$ & Oblong to ellipsoidal & Hyaline & $2.6 \mathrm{~d}$ & Spherical & Hyaline \\
\hline MH 71 & $13.5 \mathrm{~b}$ & $7.8 \mathrm{c}$ & Oblong to ellipsoidal & Hyaline & $2.6 \mathrm{~d}$ & Spherical & Hyaline \\
\hline SK-20-24 & $13.1 \mathrm{~b}$ & $7.5 \mathrm{c}$ & Oblong to ellipsoidal & Hyaline & $2.6 \mathrm{~d}$ & Spherical & Hyaline \\
\hline AP17 & $15.2 \mathrm{a}$ & $8.0 \mathrm{~b}$ & Oblong to ellipsoidal & Hyaline & $2.7 \mathrm{bcd}$ & Spherical & Hyaline \\
\hline TN 13 & $14.4 \mathrm{ab}$ & $7.6 \mathrm{c}$ & Oblong to ellipsoidal & Hyaline & $2.7 \mathrm{abc}$ & Spherical & Hyaline \\
\hline \multicolumn{8}{|l|}{ Group II } \\
\hline NAP7 & $13.4 \mathrm{~b}$ & $5.9 \mathrm{e}$ & Cylindrical to ellipsoidal & Hyaline & $2.6 \mathrm{~cd}$ & Spherical & Hyaline \\
\hline MH74 & $13.1 \mathrm{~b}$ & $6.3 \mathrm{~d}$ & Cylindrical to ellipsoidal & Hyaline & $2.6 \mathrm{bcd}$ & Spherical & Hyaline \\
\hline $\begin{array}{l}\text { Least significant } \\
\text { difference }(P=0.05)\end{array}$ & 0.89 & 0.26 & & & 0.12 & & \\
\hline \multicolumn{8}{|c|}{$\begin{array}{l}\text { Overall means of groups I and II varied significantly from one another, } P<0.0001 \text {, using linear combinations of parameters ('estimate' state- } \\
\text { ments) in PROC GLM within SAS (SAS Institute 1999). } \\
\text { a Mean of } 50 \text { conidia. } \\
\text { b Means within a column followed by a common letter(s) are not significantly different at the } 5 \% \text { level. }\end{array}$} \\
\hline
\end{tabular}

\section{Disease spread in the growth chamber}

The mean disease incidence was $71.2 \%$ for plants infected with isolate NI2 (Group I) and $15.1 \%$ for plants infected with isolate NAP7 (Group II), with an least significant difference (LSD) value $(P=0.05)$ of $18.8 \%$. Disease severity was 5.36 for NI2 and 0.42 for NAP7 with an LSD value of 2.9. Substantially more plants adjacent to the focus of infection were infected compared with those that were more distant from the focus of infection.

\section{Discussion}

This study has provided the opportunity for a comparison of two distinct groups of Claviceps isolates causing sorghum ergot in India. From our observations of the morphology of Group I and Group II isolates from India, and in light of prior descriptions that compared morphology of the two species originating from different continents (Frederickson et al. 1991;

Table 4 - Morphological characteristics of sclerotia (with and without sphacelial cap) of sorghum ergot isolates in Group I and Group II

\begin{tabular}{|c|c|c|c|c|c|c|c|c|}
\hline \multirow[t]{2}{*}{ Isolate } & \multicolumn{4}{|c|}{ Sclerotia with sphacelial cap } & \multicolumn{4}{|c|}{ Sclerotia without sphacelial cap } \\
\hline & $\begin{array}{l}\text { Length }^{a, b} \\
\text { (mm) }\end{array}$ & $\begin{array}{l}\text { Breadth }{ }^{a, b} \\
\quad(\mathrm{~mm})\end{array}$ & Shape & Colour & $\begin{array}{l}\text { Length }^{\mathrm{a}, \mathrm{b}} \\
\text { (mm) }\end{array}$ & $\begin{array}{l}\text { Breadth }{ }^{a, b} \\
\quad(\mathrm{~mm})\end{array}$ & Shape & Colour \\
\hline \multicolumn{9}{|l|}{ Group I } \\
\hline NAP12 & $4.42 \mathrm{~d}$ & $1.82 \mathrm{~b}$ & Conical to spherical & LYB $^{c}$ & $2.20 \mathrm{~b}$ & $1.30 \mathrm{c}$ & Conical to spherical & $\mathrm{RB}^{\mathrm{d}}$ \\
\hline AK1 & $4.40 \mathrm{~d}$ & $1.40 \mathrm{c}$ & Conical to spherical & LYB & $2.20 \mathrm{~b}$ & $1.20 \mathrm{c}$ & Conical to spherical & $\mathrm{RB}$ \\
\hline SK-20-24 & $4.10 \mathrm{e}$ & $1.94 \mathrm{ab}$ & Spherical to conical & LYB & $2.30 \mathrm{~b}$ & $1.20 \mathrm{c}$ & Conical to spherical & $\mathrm{RB}$ \\
\hline \multicolumn{9}{|l|}{ Group II } \\
\hline NAP4 & $9.40 \mathrm{a}$ & $1.84 \mathrm{~b}$ & Cylindrical to conical & LYB & $3.80 \mathrm{a}$ & $2.00 \mathrm{ab}$ & Oblong to cylindrical & $\mathrm{RB}$ \\
\hline NAP5 & $8.16 \mathrm{c}$ & $1.84 \mathrm{~b}$ & Cylindrical to conical & LYB & $3.80 \mathrm{a}$ & $2.10 \mathrm{a}$ & Oblong to cylindrical & $\mathrm{RB}$ \\
\hline NAP7 & $9.12 \mathrm{~b}$ & $2.04 \mathrm{a}$ & Cylindrical to conical & LYB & $3.70 \mathrm{a}$ & $2.30 \mathrm{a}$ & Oblong to cylindrical & $\mathrm{RB}$ \\
\hline NAP13 & $9.60 \mathrm{a}$ & $1.82 \mathrm{~b}$ & Cylindrical to conical & LYB & $3.90 \mathrm{a}$ & $2.20 \mathrm{a}$ & Oblong to cylindrical & $\mathrm{RB}$ \\
\hline $\begin{array}{l}\text { Least significant } \\
\text { difference }_{(P=0.05)}\end{array}$ & 0.21 & 0.147 & & & 0.266 & 0.223 & & \\
\hline \multicolumn{9}{|c|}{ a Mean of 25 sclerotia. } \\
\hline \multicolumn{9}{|c|}{$\begin{array}{l}\text { b Means within a column followed by same letter(s) are not significantly different at the } 5 \% \text { level. Overall means of Groups I and II for length and } \\
\text { breadth of sclerotia with sphacelial cap varied significantly from one another, } P<0.0001 \text { based on estimates of linear combinations of } \\
\text { parameters ('estimate' statements) in PROC GLM within SAS (SAS Institute 1999). }\end{array}$} \\
\hline
\end{tabular}



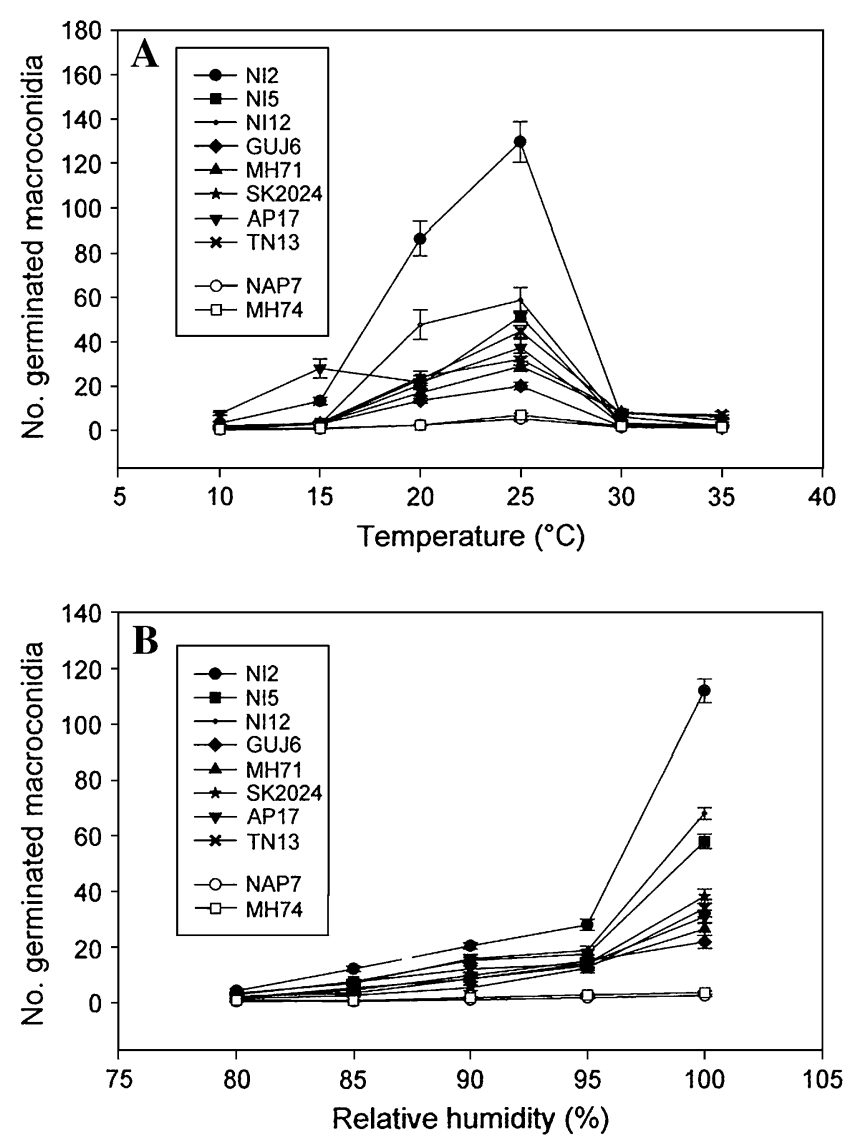

Fig 4 - Effects of temperature (A) and relative humidity (B) on secondary conidia production measured by assessing germination of macroconidia of representative isolates from Group I and Group II. The upper eight isolates on each graph (designated by solid symbols) represent Group I isolates while the lower two (designated by open symbols) represent Group II isolates. Data are means of nine observations (three replications in each of three experiments with 1000 macroconidia assessed per replication) per isolatetemperature or isolate-relative humidity combination. Standard error bars are shown on the graphs.

Kulkarni et al. 1976) we conclude that Group I isolates represent Claviceps africana and Group II isolates represent C. sorghi. Based on our 2000 survey of sorghum ergot in India, we found five isolates to represent $C$. sorghi and the remaining 84 to be C. africana. The $C$. sorghi isolates occurred from the states of Andhra Pradesh and Maharashtra. Pažoutová and Bogo (2001) also collected a C. sorghi isolate from Gulbarga in the state of Karnataka. It thus appears that $C$. sorghi is still present within India, but at a low frequency compared with C. africana. It has been suggested that $C$. sorghi was gradually replaced by C. africana in India due to the propensity for C. africana to spread more quickly due to its the large-scale production of secondary conidia (Bandyopadhyay et al. 2002; Pažoutová et al. 2000). Results of our work appear to support this hypothesis. However, there appear to be some localized areas in India, such as drought-prone northern Karnataka, where C. sorghi remains more prevalent than C. africana (Johnson \& Rajasab 2003).
Notable differences in cultural characteristics and morphology were observed among the Group I (C. africana) and Group II (C. sorghi) isolates we collected. The growth of C. sorghi isolates was cottony and velvety with aerial hyphae, and cultures were non-sulcate. Similar observations were reported by Ramakrishnan (1948) and Nagarajan and Saraswathi (1975) in describing C. sorghi. We found the $C$. sorghi isolates to sporulate on Kirchoff's medium, and then infect sorghum male sterile line 296A. Similar results were obtained by Chinnadurai (1972). But contrary to their reports of profuse sporulation of $C$. sorghi on Kirchoff's medium, we found sporulation to be sparse on T2 agar medium. This may be attributed to the differences in the medium used, or may suggest genotypic variation among isolates. The cultural characters we observed in the Group I (C. africana) isolates we collected were quite different from those of $C$. sorghi and in agreement with those described by Bogo and Mantle (1999). C. africana isolates were compact, fleshy, white, sulcate (with a low to high degree of puckering) and failed to sporulate on T2 medium. No puckering was observed in C. sorghi isolates.

The rate of growth of $C$. africana isolates was low compared with that of C. sorghi. Sphacelia of the C. sorghi isolates were substantially greater in length and breadth than those of $C$. africana. The sphacelia of $C$. sorghi isolates were white, bilaterally grooved, and more cylindrical than those of C. africana. This is in agreement with observations made by Sangitrao and Bade (1979) and Frederickson et al. (1991). Sphacelia of C. africana were white and oval to spherical in shape, in agreement with the work of Frederickson et al. (1991). C. africana sphacelial lengths ranged from $2.92-3.60 \mathrm{~mm}$, which contrasts with observations (5-8 mm) of Frederickson et al. (1991). This difference may be due to variation in ovary size of the sorghum genotypes used in the two studies.

Our study supports the observations made by Kulkarni et al. (1976) and Frederickson et al. (1991) on macroconidial morphology in C. sorghi and C. africana, respectively. Macroconidia of $C$. sorghi and C. africana isolates differed distinctly. While the conidia of the former were more cylindrical, measuring 9-18 $\times$ 5.1-7.7 $\mu \mathrm{m}$, the latter were oblong measuring of $9-18 \times 5.1-9 \mu \mathrm{m}$. The shape and size of the microconidia recorded in this study agree with the dimensions given by Kulkarni et al. (1976), Bandyopadhyay et al. (1990) and Frederickson et al. (1991). In our study no significant variation in shape and size of microconidia was observed in different sorghum ergot isolates. Similar observations were made by Sangitrao (1982) and Frederickson et al. (1991).

None of the isolates we studied produced sclerotia in infected sorghum male sterile line 296 A following artificial inoculation, even under very favourable environmental conditions for sclerotial production in growth chambers. This may be attributable to an unfavourable host genotype on which no sclerotial production occurred. However, sclerotia formed under natural conditions in seven ergot isolates collected during the survey. The sclerotia obtained from farmers' fields during the survey were formed on sorghum cultivars $\mathrm{CSH} 9$, MSH 51 and JK 22. These genotypes therefore appear to favour sclerotial production upon infection by the pathogen under optimum environmental condition. Sangitrao (1982) attributed the variation in the size of sclerotia to variation in host genotypes that favour sclerotial production. In our study, 
Table 5 - Intercepts, linear and quadratic slopes for evaluating effects of temperature and relative humidity (RH) on secondary conidia production by representative Group I and Group II Claviceps isolates collected in India ${ }^{a}$

\begin{tabular}{|c|c|c|c|c|c|c|}
\hline \multirow[t]{2}{*}{ Isolate } & \multicolumn{3}{|c|}{ Temperature $\left(10-35^{\circ} \mathrm{C}\right)$} & \multicolumn{3}{|c|}{ Relative humidity (80-100\%) } \\
\hline & Intercept & Liner slope & Quadratic slope & Intercept & Linear slope & Quadratic slope \\
\hline \multicolumn{7}{|l|}{ Group I } \\
\hline NI2 & -227.08 & 27.60 & -0.61 & 3106.73 & -73.34 & 0.43 \\
\hline NI5 & -77.47 & 9.15 & -0.20 & 1328.91 & -31.68 & 0.19 \\
\hline NI12 & -112.16 & 13.47 & -0.30 & 1738.33 & -41.20 & 0.24 \\
\hline GUJ6 & -31.08 & 3.92 & -0.09 & 104.55 & -3.12 & 0.02 \\
\hline MH71 & -44.30 & 5.39 & -0.12 & 383.98 & -9.49 & 0.06 \\
\hline SK 20-24 & -54.79 & 6.63 & -0.14 & 723.00 & -17.39 & 0.11 \\
\hline AP17 & -40.64 & 6.59 & -0.16 & 617.22 & -14.90 & 0.09 \\
\hline TN13 & -68.27 & 8.07 & -0.17 & 915.49 & -21.72 & 0.13 \\
\hline \multicolumn{7}{|l|}{ Group II } \\
\hline NAP7 & -6.66 & 0.77 & -0.02 & 33.69 & -0.83 & 0.01 \\
\hline MH74 & -8.30 & 1.01 & -0.02 & 31.20 & -0.79 & 0.01 \\
\hline $\begin{array}{l}\text { Least significant } \\
\text { difference, } P=0.01^{b}\end{array}$ & & 7.089 & 0.152 & & 10.25 & 0.11 \\
\hline
\end{tabular}

sclerotia that formed on the same sorghum cultivar (CSH 9) infected by either $C$. sorghi or $C$. africana varied distinctly in their length, suggesting the possible role of genetic variation in the production of sclerotia by C. sorghi and C. africana. Sclerotia of C. sorghi were larger than those of C. africana (Table 4), and the size of the sclerotia was further influenced by the amount and length of sphacelial tissue present on the surface of the sclerotia. However, sclerotial colour both with and without the sphacelial cap was identical in the two species.

C. africana isolates produced secondary conidia more profusely than C. sorghi isolates in our study. However, the amount of secondary conidia production within C. africana isolates varied not only between isolates but also at different temperature and $\mathrm{RH}$ regimes. In in vitro studies in Australia, the temperature optimum for secondary conidia production by $\mathrm{C}$. africana was reported as $20^{\circ} \mathrm{C}$ and no secondary conidia were produced at $\geq 30{ }^{\circ} \mathrm{C}$ (Bhuiyan et al. 2002). Our in vivo studies showed $25^{\circ} \mathrm{C}$ and $100 \% \mathrm{RH}$ as optimal conditions for secondary conidia production. Secondary conidia also were produced at 30 and $35^{\circ} \mathrm{C}$, but at a much lower frequency. Thus, C. africana isolates not only had the ability to produce large numbers of secondary conidia under optimal conditions, but also could produce a sufficient number of secondary conidia over a range of environmental conditions $\left(15-35^{\circ} \mathrm{C}\right.$ and $85-100 \% \mathrm{RH})$. Variation in secondary conidia production among isolates within the groups across temperature regimes may be attributable to the climatic adaptations of the isolates to their respective locality of origin. We observed that the isolates originating from northern India (Uttar Pradesh and Rajasthan states) produced greater numbers of secondary conidia at $25^{\circ} \mathrm{C}$ compared with isolates of southern Indian origin. This may be attributed to the similar environmental conditions (slightly warmer and more humid) that prevail in northern India, to which the isolates may have become adapted. In addition, at $35{ }^{\circ} \mathrm{C}$ isolates MH71, SK-20-24 and TN13 produced larger numbers of secondary conidia compared with other isolates from northern India (NI2, NI5 and NI12). This may be due to the existence of higher temperatures $\left(>30^{\circ} \mathrm{C}\right)$ in the region of origin of such isolates.

Though sorghum ergot may spread through ascospores and macroconidia, spread by secondary conidia is of prime concern in the epidemiology of the disease. Indeed, secondary conidia have been implicated in the rapid spread of $C$. africana (Frederickson et al. 1993; Bandyopadhyay et al. 1998). In many cases, failure of germination by sclerotia is reported (Bandyopadhyay et al. 1996). In the absence of ascospores, and rainsplash to disseminate the macroconidia, the spread of the disease is effectively carried out through airborne secondary conidia. Differences we observed in secondary conidia production between C. africana and C. sorghi isolates corresponded to the existence of higher levels of airborne spread of $C$. africana versus $C$. sorghi in the growth chamber experiments. Profuse production of secondary conidia by $C$. africana and negligible production by $C$. sorghi is in agreement with earlier findings (Frederickson et al. 1989; Bandyopadhyay et al. 1996).

The cultural, morphological and epidemiological evidence we collected in determining which of our isolates represent C. africana versus C. sorghi was supported by evidence from AFLP and DNA sequencing studies which also clearly distinguished C. africana from C. sorghi (Tooley et al. 2006). This study also suggests that a previous report (Bandyopadhyay et al. 1990) on the biology of the ergot pathogen in India dealt with C. africana and not C. sorghi as described in the report.

Of the 89 isolates collected and studied in the present investigation only five isolates (NAP 4, NAP 5, NAP 7, NAP 13, and $\mathrm{MH}$ 74) were $C$. sorghi and 84 isolates were $C$. africana, indicating the vast predominance of $C$. africana in major sorghum growing areas of India during the period in which these collections were made. C. sorghi, being found in such low frequency in India, having low propensity to spread through secondary conidia, and not reported to occur elsewhere in the world, currently appears to represent little 
threat to other major sorghum producing regions of the world.

\section{Acknowledgements}

We sincerely thank Dana Berner (USDA-ARS Foreign DiseaseWeed Science Research Unit) for his assistance with statistical analysis. We also acknowledge the assistance of Shrishail S. Navi and Vilas Tonapi for collection of ergot samples in India. This work was carried out under USDA-ARS Agreement no. 58-1920-9-F110.

\section{R E F E R E N C E S}

Ajrekar SL, 1926. Observations on a disease of Jowar (Sorghum vulgare) caused by Sphacelia (conidial stage Claviceps). Journal of the Indian Botanical Society 5: 55-61.

All India Coordinated Sorghum Improvement Project (AICSIP), 1969-1970. Progress report of the all India coordinated sorghum improvement project. 1969-70. Indian Council of Agricultural Research and Cooperative Agencies, New Delhi, pp. 138-146.

Bandyopadhyay R, Mughogho LK, Manohar SK, Satyanarayana MV, 1990. Stroma development and honeydew formation, and conidial production in Claviceps sorghi. Phytopathology 80: 812-818.

Bandyopadhyay R, Frederickson DE, McLaren NW, Odvody GN, 1996. Ergot-a global threat to sorghum. International Sorghum and Millet Newsletter 37: 1-32.

Bandyopadhyay R, Frederickson DE, McLaren NW, Odvody GN, Ryley MJ, 1998. Ergot: a new disease threat to sorghum in the Americas and Australia. Plant Disease 82: 356-367.

Bandyopadhyay R, Muthusubramanian V, Tooley PW, Chakraborty S, Pažoutová S, Navi SS, 2002. Distribution and diversity of the sorghum sugary disease pathogens in India. In: Leslie JF (ed), Sorghum and Millet Diseases 2000. Iowa State University Press, Ames, IA, pp. 75-78.

Bhuiyan SA, Galea VJ, Ryley MJ, Tay D, Lisle AT, 2002. Factors influencing the germination of macroconidia and secondary conidia of Claviceps africana. Australian Journal of Agricultural Research 53: 1087-1094.

Bogo A, Mantle PG, 1999. Claviceps africana discovered in India. Plant Disease 83: 79.

Butler DR, Reddy RK, Wadia KR, 1995. Single-plant chambers to control humidity for pathological studies. Plant Pathology 44: 1-9.

Chinnadurai G, 1972. Effect of certain trace elements on the growth and sporulation of Sphacelia sorghi. Indian Phytopathology 25: 599-600.

Frederickson DE, Mantle PG, De Milliano WAJ, 1989. Secondary conidiation of Sphacelia sorghi on sorghum, a novel factor in the epidemiology of ergot disease. Mycological Research 93: 497502.

Frederickson DE, Mantle PG, de Milliano WAJ, 1991. Claviceps africana sp. nov., the distinctive ergot pathogen of sorghum in Africa. Mycological Research 95: 1101-1107.

Frederickson DE, Mantle PG, de Milliano WAJ, 1993. Windborne spread of ergot disease (Claviceps africana) in sorghum A-lines in Zimbabwe. Plant Pathology 42: 368-377.

Frederickson D, Odvody G, Isakeit T, 1999. Sorghum Ergot: Distinguishing Sphacelia and Sclerotia of Claviceps africana in Seed (Publication No. L-5315.). Agricultural Communications, Texas A\&M University System, College Station, TX.
Lane PW, Payne RW, 1999. Genstat for Windows: an Introductory Course, 4th edn. Numerical Algorithms Group, Oxford.

Johnson N, Rajasab AH, 2003. Prevalence of Claviceps sorghi in Karnataka, India. International Sorghum and Millets Newsletter 44: 93-95.

Komolong B, Chakraborty S, Ryley M, Yates D, 2002. Identity and genetic diversity of the sorghum ergot pathogen in Australia. Australian Journal of Agriculture Research 53: 621-628.

Kulkarni GS, 1942. Ergot in India. Current Science 11: 246.

Kulkarni BGP, Seshadri VS, Hegde RK, 1976. The perfect stage of Sphacelia sorghi McRae. Mysore Journal of Agricultural Science 10: 286-289.

Munsell Products, 1973. Munsell Soil Color Charts Macbeth Color \& Photometry Division. Kollmorgen Corporation, Baltimore, MD.

Nagarajan K, Saraswathi V, 1975. Production of honeydew line secretions in the culture of Sphacelia sorghi. Indian Phytopathology 28: 110.

Nath P, Padwick GW, 1941. Ergot in India. Current Science 10: 488489.

Navi SS, Bandyopadhyay R, Nageswara Rao TG, Tooley PW, 2002a. An outbreak of sorghum ergot in parts of Andhra Pradesh, India. International Sorghum and Millets Newsletter 43: 68-70.

Navi SS, Bandyopadhyay R, Tonapi VA, Nageshwar Rao TG, Tooley PW, Reddy RK, Indira S, Pande S, 2002b. Prevalence of ergot of sorghum in India. International Sorghum and Millets Newsletter 43: 70-71.

Patil PY, Raut NK, Deshpande PM, 1968. A note on the occurrence of ergot; sugary disease on the hybrid Jowar in Maharashtra (Parbhani). College of Agriculture, Parbhani Magazine 4: 93-94.

Pažoutová S, Bandyopadhyay R, Frederickson DE, Mantle PG, Frederiksen RA, 2000. Relations among sorghum ergot isolates from the Americas, Africa, India and Australia. Plant Disease 84: 437-442.

Pažoutová S, Bogo A, 2001. Rediscovery of Claviceps sorghi (Ascomycotina: Clavicipitaceae) in India. Mycopathologia 153: 99-101.

Pažoutová S, Kolarik M, Kolinska R, 2004. Pleomorphic conidiation in Claviceps. Mycological Research 108: 126-135.

Ramakrishnan TS, 1947. The natural occurrence of ergot in south India. Proceedings Indian Academy of Sciences 26: 136-141.

Ramakrishnan TS, 1948. Ergot sclerotia on Sorghum vulgare Pers. Current Science 17: 218.

Sangitrao CS, 1982. Studies on ergot disease of sorghum in Vidarbha. PhD thesis, Punjabrao Krishi Vidyapeeth, Akola, India.

Sangitrao CS, Bade GH, 1979. Meteorological factors associated with honeydew development and sclerotial stage in sorghum ergot. Sorghum Newsletter 22: 107-108.

SAS Institute, 1999. SAS/STAT. Version 8 manual. SAS Institute, Cary, NC.

Sundaram NV, 1969. Current plant pathological problems in new agricultural strategy with special reference to sorghum and millets. Indian Phytopathological Society Bulletin 4: 62-72.

Thomas KM, Ramakrishnan TS, Shrinivasan KV, 1945. Natural occurrence of ergot in south India. Proceedings of the Indian Academy of Sciences, B 21: 93-100.

Tooley PW, O'Neill NR, Goley ED, Carras MM, 2000. Assessment of diversity in Claviceps africana and other Claviceps species by RAM and AFLP analyses. Phytopathology 90: 1126-1130.

Tooley PW, Goley ED, Carras MM, O'Neill NR, 2002. AFLP comparisons among Claviceps africana isolates from the United States, Mexico, Africa, Australia, India, and Japan. Plant Disease 86: 1247-1252.

Tooley PW, Bandyopadhyay R, Carras MM, Pažoutová S, 2006. Analysis of Claviceps africana and $C$. sorghi from India using AFLPs, EF- $1 \alpha$ gene intron 4 and $\beta$-tubulin gene intron 3 . Mycological Research 110: 441-451.

Tsukiboshi T, Shimanuki T, Uematsu T, 1999. Claviceps sorghicola sp. nov., a destructive ergot pathogen of sorghum in Japan. Mycological Research 103: 1403-1408. 